\title{
PEMAHAMAN KONSEP TUBUH MANUSIA DAN KESULITAN-KESULITAN DALAM MENGUASAINYA PADA MAHASISWA PROGRAM S-1 PGSD UPI KAMPUS CIBIRU
}

\author{
H. Dede Margo Irianto
}

\begin{abstract}
ABSTRAK
Secara umum penelitian ini bertujuan untuk mencari alternatif program perkuliahan di Program S1 PGSD UPI Kampus Cibiru, secar khusus penelitian ini dilaksanakan untuk mengetahui tingkat penguasaan konsep IPA, khususnya pada sub konsep tubuh manusia mahasiswa Program S1 PGSD UPI Kampus Cibiru, memperoleh informasi tentang kesulitan-kesulitan yang dialami oleh mahasiswa, dan memperoleh ionformasi tenatng faktor-faktor yang menyebabkan kesulitan belajar mahasiswa.
\end{abstract}

\section{Kata Kunci: Pemahaman Konsep, Kesulitas Pemahaman, konsep tubuh manusia}

\section{A. Pendahuluan}

Perubahan jenjang program dari program D-II ke program S1 pada program Studi PGSD membawa perubahan yang perlu dicermati, diantaranya adalah berkurangnya jumlah SKS untuk mata kuliah yang sama. Hal itu terjadi pada mata kuliah Konsep Dasar IPA SD yang semula memiliki bobot 4 SKS menjadi 3 SKS, sedangkan isi materi perkuliahan tidak berubah. Alasan lain yang mendorong penelitian ini adalah, kurang baiknya hasil akhir mahasiswa Program S1 PGSD pada mata kuliah ini, yang notabene juga menunjukkan penguasaan konsep mahasiswa yang belum sesuai dengan tujuan yang telah ditentukan, khususnya pada sub konsep tubuh manusia.

Konsep tubuh manusia dipilih karena konsep ini memiliki porsi yang cukup tinggi pada pembelajaran IPA di SD, karena itu seorang guru di SD seyogyanya menguasai konsep ini dengan baik.

Berdasarkan latar belakang yang telah diungkapkan di atas, rumusan masalah dalam penelitian ini adalah "Bagaimanakah tingkat kecenderungan penguasaan konsep tubuh manusia mahasiswa Program S1 PGSD UPI Kampus Cibiru?" Masalah di atas dijabarkan dalam pertanyaan penelitian sebagai beikut : 1) Sejauh mana tingkat penguasaan konsep tubuh manusia mahasiswa Program S1 PGSD UPI Kampus Cibiru?, 2) Kesulitan apa saja yang dialami mahasiswa Program S1 PGSD UPI Kampus Cibiru dalam menguasai konsep tubuh manusia?, dan 3) Faktor-faktor apa saja yang mempengaruhi kesulitan belajar mnahasiswa Program S1 PGSD UPI Kampus Cibiru?

\section{B. Tinjauan Pustaka}

\section{Pengertian Konsep Belajar IPA}

Salah satu kegiatan dalam proses belajar -mengajar adalah mempelajari konsepkonsep. Belajar konsep adalah suatu hal yang penting dalam belajar di sekolah. Ada beberapa definisi tentang belajar, diantaranya diungkapkan oleh Hilgard (Nasution, 1986), belajar adalah proses yang melahirkan atau mengubah suatu kegiatan melalui latihan (apakah dalam laboratorium atau dalam lingkungan alamiah) yang dibedakan dari perubahan-perubahan oleh faktor-faktor yang tidak termasuk latihan. Gagne (1985) 
mendefinisikan belajar sebagi prosews perubahan perilaku pada manusia sebagai akibat pengalaman.

Kedua definisi tersebut sejalan. Intinya bahwa dalam belajar akan terjadi perubahan peilaku. Perubahan perilaku dalam kegiatan belajar disebabkan pengalaman. Pengalaman atau latihan ini membedakan perubahan lain yang bukan termasuk hasil belajar seperti yang bersifat fisiologis maupun kematangan.

Sama halnya dengan belajar, definisi konsep juga dapat bermacam-macam. Dalam uraian berikut diutarakan beberapa definisi konsep diantaranya yang didefinisikan oleh Farel (1980) "A concept is a clssification of objects. Object properties, or events into a set by process of abstraction" Gagne (1985) menyatakan bahwa "A concept .... is an abstract idea with enables people to classify objects or even are examples or non examples" Kedua definisi tersebut sejalan yang diungkapkan oleh Rusefendi (1986) yang menyatakan bahwa konsep adalah suatu ide aabstrak yang memungkinkan kita mengelompokkan benda-benda (obyek) ke dalam contoh dan bukan contoh.

Konsep dapat dipelajari melalui observasi ataupun definisi. Melalui observasi langsung, seorang anak dapat belajar menggolongkan makhluk hidup. Misalnya dari sekumpulan makhluk hidup, siswa dapat menggolongkkannya menjadi kelompok tumbuhan dan kelompok hewan. Namun demikian, walaupun mereka dapat menggolongkannya, tidak semua dari mereka dapat mengungkapkan definisi tentang konsep hewan dan tumbuhan.

Konsep dapat diklasifikasikan menjadi dua yaitu konsep berdasarkan pada observasi dan konsep berdasarkan definisi. Konsep berdasarkan observasi merupakan abstraksi dari persepsi terhadap contoh dan bukan contoh, sedangkan konsep berdasarkan definisi adalah konsep yang berbentuk rumusan verbal.

Dalam proses belajar mengajar IPA akan dijumpai tujuan-tujuan yang akan dicapai, yang disusun berdasarkan taksonomi Bloom tentang tujuan-tujuan perilaku. Taksonomi Bloom meliputi tiga macam domain, yaitu domain kognitif, afektif dan psikomotorik. Gagne (1985) mengemukakan lima macam hasil belajar, yaitu informasi verbal, keterampilan intelektual, strategi kognitif, sikap, dan keterampilan motorik. Tiga diantaranya adalah kognitif, satu bersifat afektif, dan satu lainnya bersifat psikomotorik.

Tingkah laku atau penampilan yang dapat diamati sebagai hasil belajar disebut kemampuan atau capabilities (Gagne, 1975). Kemampuan yang diharapkan sebagai hasil pengajaran perlu dibedakan, karena setiap kemampuan memungkinkan berbagai macam penampilan manusia. Selain itu untuk memperoleh kemampuan yang berbedabeda diperlukan kondisi yang berbeda pula.

Gagne mengemukakan bahwa keterampilan intelektual merupakan salah satu katagori hasil belajar. Sub-sub katagori keterampilan intelektual tersebut secara hierarki tersusun dari operasi mental yang paling sederhana sampai ke yang lebih kompleks. Sub-sub keterampilan intelektual menurut Gagne (1985) adalah : diskriminasi, konsep konkrit, konsep terdefinisi, aturan, dan aturan tingkat tinggi atau pemecahan masalah.

\section{Proses Belajar Mengajar IPA}

Pendidikan IPA (SAINS) merupakan salah satu ilmu pengetahuan, dengan menggunakan IPA sebagai alat untuk mencapai tujuan. Salah satu sasaran yang dapat dicapai melalui pendidikan IPA adalah pendidikan IPA itu sendiri dalam arti seseorang 
yang belajar IPA mampu memaknai hakikat IPA sebagai produk, proses, dan hakikat IPA sebagai sikap. Dalam mempelajari IPA diharapkan setiap siswa bertambah pengetahuannya mengenai fakta, data, konsep, dan prinsip; mempunyai sikap ilmiah; bersedia menggunakan daya pikirnya untuk memecahkan masalah yang dihadapinya dengan mempergunakan metode ilmiah; pengajaran IPA bertujuan menanamkan konsep dan prinsip IPA kepada siswa menurut pengertian di atas. Ada yang menekankan pengertian secara keseluruhan, tetapi ada juga yang hanya sebagian, sebab menganggap bila bagian yang ditekankan itu tercapai, bagian yang lain akan dicapai pula.

Dari dua pendapat yang berbeda seperti diuraikan di atas, maka dalam pendidikan IPA hendaknya siswa tidak hanya memperoleh produk IPA saja, tetapi juga diharapkan menguasai proses dan sikap ilmiah. Untuk itu perlu diciptakan lingkungan belajar yang memungkinkan siswa terlibat dalam berbagai macam kegiatan. Hendaknya siswa belajar IPA dengan banyak berbuat sesuatu, dan belajar bersikap seperti apa yang telah diperbuat oleh para ilmuwan IPA sebelumnya. Mengajar IPA bukan sekedar mengungkapkan fakta-fakta ke dalam benak siswa melainkan lebih menitik beratkan mengajak siswa berperan serta dalam proses yang memungkinkan penyerapan pengetahuan. Teori pembelajaran yang digunakan dalam pendidikan IPA harus berlandaskan kepada kenyataan bahwa kurikulum IPA tidak hanya mencerminkan pengetahuan, tetapi juga hakikat anak dan proses mendapatkan pengetahuan. Conny (1982) menyatakan bahwa pendidikan IPA seyogyanya mulai memberikan kesempatan lapangan, latihan untuk berpikir logis, kreatif dan obyektif sehingga proses pengembangan dalam pendidikan IPA benar-benar dapat terpenuhi.

Kegiatan pembelajaran tidak hanya dimaksudkan untuk menjejalkan fakta-fakta ke dalam kepala siswa. Tetapi membantu siswa agar mampu belajar untuk diri sendiri. Suatu kesadaran tentang bagaimana sulitnya menanamkan suatu konsep, pengertian dan memecahkan suatu masalah akan dapat membantu siswa dalam mengembangkan keterampilan proses.

\section{Pengajaran Yang Efektif}

\section{a. Pengertian Pengajaran}

Menurut Sumantri (1988) pengajaran adalah alat atau proses yang dilakukan oleh guru untuk membimbing, membantu dan mengarahkan peserta didik untuk memiliki pengalaman belajar. Dalam konteks yang sama, Nasution (1989) mengatakan bahwa pengajaran adalah proses interaksi yang berlangsung antara guru dengan mahasiswa atau juga antara sekelompok mahasiswa dengan tujuan untuk memperoleh pengetahuan, keterampilan, atau sikap serta memantapkan apa yang telah dipelajari. Menganalisis dua pengertian tersebut, pengajaran merupakan suatu cara bagaimana mempersiapkan pengalaman belajar bagi peserta didik sehingga mahasiswa memiliki karakteristik yang sesuai dengan tujuan.

b. Komponen Pengajaran

Selain pengertian pengajaran, untuk menciptakan pengajaran yang efektif, kita perlu juga memperhatikan komponen-komponen pengajaran, yang meliputi tujuan pengajaran, isi pengajaran, metode pengajaran, alat pengajaran, dan penilaian pengajaran. Komponen-komponen tadi saling mendukung satu dengan yang lainnya. Diperlukan kemampuan dan keterampilan guru di dalam mengkombinasikan, memilih, 
dan meramu komponen tersebut sehingga membentuk suatu kesatuan yang utuh dan sinergis untuk menciptakan pengajaran yang efektif.

. tujuan, bahan, metode, waktu, dan sarana yang ada. Oleh karena itu, seorang dosen harus mahir memilih alat peraga yang tepat dalam melaksanakan kegiatan belajar mengajar, untuk mencapai hasil yang baik.

\section{Kondisi Belajar Mengajar Yang Efektif}

Guru memiliki peranan yang sangat penting dalam menentukan kualitas pengajaran yang dilaksanakannya. Oleh karena itu guru harus memikirkan dan membuat perencanaan yang seksama dalam meningkatkan kesempatan belajar pada peserta didiknya guna memperbaiki kualitas mengajarnya.

Untuk menciptakan kondisi belajar mengajar yang efektif diperllukan beberapa variabel yang menentukan keberhasilan belajar peserta didik. Adapun variabel-variabel tersebut adalah : Pertama; Keaktifan siswa. Aktivitas siwa yang dimaksud adalah aktivitas visula, aktivitas lisan, aktivitas mendengarkan, aktivitas gerak, dan aktivitas menulis. Setiap aktivitas tersebut memiliki bobot yang berbeda-beda tergantung pada tujuan yang akan dicapai dalam kegiatan belajar mengajar. Kedua; Menarik minat dan perhatian siswa. Minat merupakan sifat yang relatif menetap pada diri seseorang, sedangkan perhatian bersifat sementara. Minat dan perhatian ini besar sekali pengaruhnya terhadap belajar, sebab melalui minat, seseorang akan memperhatikan sesuatu yang diminatinya, sehingga pelajaran yang diterimanya dapat dipahami dengan baik. Ketiga; proses belajar mengajar yang efektif dapat membangkitkan motivasi belajar, yaitu proses untuk menggiatkan motif-motif (daya) menjadi perbuatan atau tingkah laku untuk memenuhi kebituhan dan mencapai tujuan. Keempat; memperhatikan perbedaan kemampuan siswa yakni guru memberikan pelayanan khusus bila ada siswa yang terlambat dalam menerima pelajaran. Kelima; menggunakan alat peraga yang tepat sehingga dapat mempermudah pemahaman siswa. Alat peraga ini dipergunakan sebagai media untuk diskusi, analisa, dan evaluasi pemahaman siswa.

Beberapa dari kondisi eksternal untuk terjadinya belajar yang efektif berlaku pada semua jenis hasil belajar yang diharapkan. Provisi eksternal yang diadakan untuk merangsang kesiagaan, atau perhatian, misalnya bisa sangat serupa tidak pandang kapabilitas apa yang sedang dipelajari. Sama halnya untuk kerja apapun apapun yang berkaitan dengan kapabilitas yang dipelajari - apakah tindak motorik, ucapan verbal, atau penerapan suatu kaidah haruslah ditimbulkan sebagai suatu peristiwa esensial dalam belajar, namun ada beberapa kondisi eksternal yang bersifat spesifik sesuai dengan sifat apa yang dipelajari dan berbeda dengan hasil belajar yang diharapkan. Sebagai contoh, jenis peristiwa yang mendukung proses mengkode untuk suatu keterampilan motoris sangat berbeda dengan perisyiwa yang akan memudahkan belajar informasi verbal. Mengkodekan suatu keterampilan motoris sangat dipengaruhi oleh rangsangan yang timbul di dalam otot dan yang berasal dari unjuk kerja gerakan otot. Sebaliknya pengkodean informasi verbal tidak bergantung pada tindak "menyatakan" melainkan dipengaruhi oleh makna konteks.

Selanjutnya Gagne (1985) mengatakan bahwa kondisi untuk merangsang ingatan kembali prasyarat-prasyarat sama untuk semua jenis hasil belajar. Stimulus untuk ingatan kembali itu bermaksud mengingatkan retrival apa-apa yang telah 
dipelajari sebelumnya ke memori kerja (jangka pendek) sehingga dapat diinkorporasi masuk ke dalam belajar yang baru. Namun, sifat hakikat apa yang harus diretrival jelas berbeda diantara hasil-hasil belajar itu.

Di dalam melakukan proses belajar, hendaknya diperhatikan pula bahwa materi materi yang dipelajari di waktu sebelumnya bisa mendukung belajar secara berbedabeda, bergantung pada apa-apa yang tersimpan pada siswa, sebagai contoh "konteks bermakna yang lebih besar" untuk belajar informasi (baru) sering terutama datang dari simpanan informasi (lama) yang terorganisasi dalam memori siswa.

\section{Kesulitan Belajar Mahasiswa}

Kesulitan belajar dapat diartikan sebagi suatu kondisi dalam proses belajar mengajar yang ditandai moleh adanya hambatan-hambatan tertentu untuk mencapai hasil belajar yang optimal. Hambatan-hambatan tersebut mungkin dirasakan atau mungkin tidak dirasakan oleh mahasiswa ayang bersangkutan. Jenis hambatan ini, dapat bersifat psikologis, sosiologis atau fisiologis (Mardiati, 1988).

Seorang mahasiswa dapat diduga mengalami kesulitan belajar, jika yang bersangkutan menunjukkan kegagalan tertentu dalam mencapai tujuan belajar (Borton, 1955). Lebih lanjut Borton menjelaskan pengertian kegagalan belajar dalam empat hal. Pertama, apabila dalam batas waktu tertentu mahasiswa yidak mencapai tingkat penguasaan minimal dalam pelajaran tertentu seperti yang telah ditentukan oleh dosen. Kedua yang bersangkutan tidak dapat mengerjakan atau mencapai prestasi yang semestinya, dalam arti tidak sesuai dengan kemampuan potensial yang dimilikinya. Ketiga apabila yang bersangkutan tidak dapat mewujudkan tugas-tugas perkembangan, termasuk penyesuaian sosial dengan pla organisasinya. Keempat, yang bersangkutan lambat belajar.

\section{Metode Penelitian}

Penelitian ini menggunakan metode deskriptif yaitu mendeskripsikan tingkat penguasaan konsep-konsep IPA, kesulitan dan faktor-faktor yang menyebabkannya dalam proses belajar mengajar yang berlangsung di Program S1 PGSD UPI Kampus Cibiru. Untuk mendeskripsikan hal tersebut digunakan pendekatan kuantitatif. Melalui analisis deskriptif dengan pendekatan kualitatif, data yang telah dikumpulkan, dirangkum, dan dianalisis, sehingga dapat menjadi informasi yang berarti.

Penelitian ini dilaksanakan pada Program S1 PGSD Universitas Pendidikan Indonesia Kampus Cibiru dengan melibatkan mahasiswa semester I tahun akademik 2006/2007 sebagai subyek penelitian.

Subyek penelitian ini adalah mahasiswa Program S1 PGSD UPI Kampus Cibiru semester I Tahun akademik 2006/2007. Dalam penelitian ini tidak dilibatkan seluruh kelas yang ada di UPI Kampus Cibiru, namun kelas yang diambil adalah kelas yang dipegang oleh peneliti, yaitu 3 kelas. Dari 3 kelas diambil sampel secara random satu kelas dengan jumlah mahasiswa masing-masing kurang lebih 40 orang. Jumlah mahasiswa yang di tes dalam penelitian ini 40 orang, jumlah mahasiswa yang diwawancara tiga orang, masing-masing satu dari kelompok rendah, sedang, dan tinggi.

Instrumen yang digunakan dalam penelitian ini adalah tes tertulis berbentuk uraian, format observasi dan rambu-rambu wawancara. Instrumen tersebut digunakan untuk mendapatkan data tentang kesulitan yang dialami oleh mahasiswa Program S1 
PGSD UPI Kampus Cibiru dalam menguasai konsep-konsep IPA, khususnya konsep tubuh manusia.

Teknik pengumpulan data dalam penelitian ini dilaksanakan melalui observasi, pelaksanaan tes, dan wawancara. Observasi untuk mendapatkan data tentang pelaksanaan kegiatan belajar mengajar dan interaksi antara mahasiswa dengan dosen. Melalui tes hasil belajar diperoleh data tentang tingkat penguasaan konsep tubuh manusia. Hasilnya berupa angka kemudian dikelompokkan menjadi baik, sedang, dan rendah. Melalui wawancara dengan mahasiswa tentang kesulitan yang dialami mahasiswa dalam menguasai konsep-konsep IPA, dihimpun data tentang kesulitankesulitan mahasiswa dalam mempelajari konsep tersebut.

Pengolahan data dalam penelitian ini dilakukan dengan menggunakan prosedur dan langkah-langkah sebagai berikut :

1. Mengklasifikasikan data dalam kelompok tingkat penguasaan konsep tubuh manusia, kesulitan-kesulitan yang dialami mahasiswa dalam memahami konsep tersebut dan efektifitas proses belajar mengajar dalam perkuliahan konsep tubuh manusia.

2. Memverifikasi data, untuk mengecek kebenaran data yang telah terhimpun melalui tes, observasi, dan wawancara.

3. Mengolah data dengan mengelompokannya ke dalam katagori rendah, sedang, tinggi kemudian dicari prosentasenya untuk mengetahui tingkat penguasaan konsep tubuh manusia, menemukan kesulitan-kesulitan yang dialami mahasiswa, dan tingkat efektifitas proses belajar-mengajar.

4. Menganalisa data dengan menggunakan konsep-konsep dan teori yang relevan.

\section{DESKRIPSI DAN PEMBAHASAN HASIL PENELITIAN}

Yang dimaksud dengan deskripsi data adalah penyajian temuan secara empirik yang dihimpun melalui instrumen yang digunakan yaitu tes, observasi, dan wawancara. Yang dimaksud dengan analisis data adalah pembahasan hasil penelitian dengan mencoba mengaitkannya dengan mempergunakan konsep-konsep dan teori-teori yang relevan dengan masalah yang diteliti dalam penelitian ini.

\section{Deskripsi Hasil Penelitian}

Setelah dihitung frekwensi dan presentasenya, maka data hasil penelitian ini akan disajikan dalam bentuk tabel, sedangkan hasil observasi dan wawancara akan diolah dan disajikan secara langsung, untuk memperoleh data tentang berbagai kendala yang dialami oleh mahasiswa dalam memahami konsep tubuh manusia.

Pemahaman mahasiswa terhadap konsep-konsep tubuh manusia dihitung berdasarkan skor yang diperoleh dari seluruh butir tes.

Hasil tes penguasaan konsep tubuh manusia yang telah diolah berupa skor ratarata dan standar deviasinya menunjukkan nilai tertinggi yang diperoleh mahasiswa adalah 83 , sedangkan nilai terendah yang diperoleh mahasiswa adalah 40 , skor rata-rata 61,25 .

Untuk mengetahui bagaimana pemahaman konsep tubuh manusia mahasiswa, maka data pada tabel di atas dikelompokkan pada tiga katagori, yaitu tinggi, sedang, dan rendah. Pada penelitian ini, penulis mengemukakan pendapat yang dikemukakan oleh Suharsimi (1993 : 269) yang mengatakan bahwa ketiga katagori tersebut dapat ditentukan dengan cara sebagai berikut : (1) kelompok baik (tinggi), semua peserta tes 
mempunyai skor rata-rata plus satu standar deviasi (SD) ke atas, (2) kelompok sedang mempunyai skor - 1 SD dan + 1 SD, dan (3) kelompok rendah (kurang), semua peserta tes mempunyai skor tes - 1 SD dan yang kurang dari itu. Maka berdasarkan aturan itulah, skor hasil belajar mahasiswa Program S1 PGSD UPI Kampus Cibiru dapat dikelompokkan menjadi katagori tinggi, sedang, dan rendah.

Berdasarkan data yang diperoleh, maka hasil belajar mahasiswa Program S1 PGSD UPI kampus Cibiru angkatan Tahun 2006/2007 berdasarkan katagori tinggi, sedang, dan rendah dapat dilihat pada tabel berikut :

TABEL

\section{HASIL BELAJAR MAHASISWA BERDASARKAN KATEGORI TINGGI, SEDANG, DAN RENDAH}

\begin{tabular}{|c|c|c|c|c|}
\hline $\begin{array}{c}\text { KAT } \\
\text { EGO } \\
\text { RI }\end{array}$ & KRITERIA & SKOR & $\mathrm{f}$ & $\%$ \\
\hline $\begin{array}{c}\text { Tingg } \\
\text { i }\end{array}$ & $\mathrm{X} \geq \mathrm{X}+1 \mathrm{SD}$ & $\mathrm{X} \geq 72$ & 7 & 17,5 \\
\hline $\begin{array}{c}\text { Sedan } \\
\mathrm{g}\end{array}$ & $\begin{array}{c}\mathrm{X}-1 \mathrm{SD}<\mathrm{X}<\mathrm{X} \\
+1 \mathrm{SD}\end{array}$ & $50<\mathrm{X}<72$ & 27 & 67,5 \\
\hline $\begin{array}{c}\text { Rend } \\
\text { ah }\end{array}$ & $\mathrm{X} \leq \mathrm{X}-1 \mathrm{SD}$ & $\mathrm{X} \leq 50$ & 6 & 15 \\
\hline
\end{tabular}

Melihat hasil yang diperoleh pada tabel di atas, tingkat pemahaman konsep tubuh manusia mahasiswa program S1 PGSD UPI kampus Cibiru angkatan 2006 / 2007 dapat dikategorikan menjadi tiga kelompok yaitu kelompok tinggi, kelompok sedang, dan kelompok rendah. Yang termasuk ke dalam kelompok tinggi adalah mahasiswa yang mendapat skor sebanyak skor rata-rata ditambah satu standar deviasi ke atas. Yang termasuk kelompok sedang adalah mahasiswa yang memperoleh skor antara jumlah skor rata-rata dikurangi $1 \mathrm{SD}$ dan jumlah skor rata-rata plus $1 \mathrm{SD}$. Yang termasuk kelompok rendah adalah mereka yang memperoleh skor dibawah skor ratarata minus $1 \mathrm{SD}$.

Berdasarkan pengelompokkan tersebut, diperoleh prosentase sebagai berikut. Mahasiswa kelompok tinggi 17,5\%, mahasiswa kelompok sedang 67,5\%, dan mahasiswa kelompok rendah $15 \%$. Apabila data tersebut di atas di nyatakan dalam bentuk grafik, maka akan diperoleh hasil sebagai berikut : 


\section{GRAFIK \\ HASIL BELAJAR MAHASISWA BERDASARKAN KATEGORI TINGGI, SEDANG, DAN RENDAH}

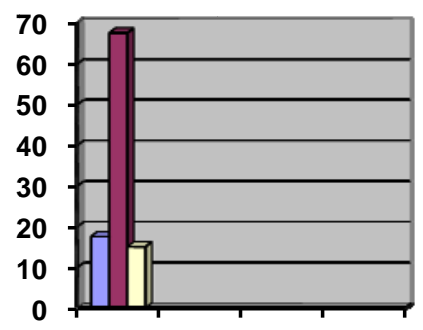

$$
\begin{aligned}
& \text { 口Tinggi } \\
& \text { םSedang } \\
& \text { םRendah }
\end{aligned}
$$

Selanjutnya penguasaan mahasiswa Program S1 PGSD UPI Kampus Cibiru tentang konsep tubuh manusia, dibagi ke dalam 6 sub konsep, yaitu (1) sistem rangka dan sistem otot, (2) sistem pencernaan, (3) sistem transportasi, (4) sistem pernafasan, dan (5) alat indera.

Berdasarkan hasil tes yang diperoleh mahasiswa, maka pengolahannya untuk masing-masing sub konsep adalah sebagai berikut :

TABEL

HASIL TES PENGUASAAN KONSEP SISTEM RANGKA DAN SISTEM OTOT

\begin{tabular}{|c|c|c|c|}
\hline SKOR & $\mathrm{F}$ & $\%$ & KATEGORI \\
\hline $\mathrm{X} \geq 10$ & 14 & 35 & Tinggi \\
$10<\mathrm{X}<5$ & 18 & 45 & Sedang \\
$\mathrm{X} \leq 5$ & 8 & 20 & Rendah \\
\hline Jumlah & 40 & 100 & \\
\hline
\end{tabular}

Dari tabel di atas terlihat bahwa penguasaan konsep tubuh manusia pada sub konsep sistem rangka dan sistem otot mahasiswa Program S1 PGSD UPI Kampus Cibiru $35 \%$ berada pada kategori tinggi, $45 \%$ berada pada kategori sedang, dan $20 \%$ berada pada kategori rendah.

Berdasarkan hasil di atas, dapat ditarik kesimpulan bahwa secara umum, kecenderungan penguasaan konsep tubuh manusia pada sub konsep sistem rangka, mahasiswa Program S1 PGSD UPI Kampus Cibiru berada pada tingkat sedang. 
TABEL

HASIL TES PENGUASAAN KONSEP SISTEM PENCERNAAN

\begin{tabular}{|c|c|c|c|}
\hline SKOR & $\mathrm{F}$ & $\%$ & KATEGORI \\
\hline $\mathrm{X} \geq 10$ & 19 & 47,5 & Tinggi \\
$10<\mathrm{X}<5$ & 15 & 37,5 & Sedang \\
$\mathrm{X} \leq 5$ & 6 & 15 & Rendah \\
\hline Jumlah & 40 & 100 & \\
\hline
\end{tabular}

Dari tabel di atas terlihat bahwa penguasaan konsep tubuh manusia pada sub konsep sistem pencernaan mahasiswa Program S1 PGSD UPI Kampus Cibiru 47,5 $\%$ berada pada kategori tinggi, 37,5 \% berada pada kategori sedang, dan $15 \%$ berada pada kategori rendah.

Berdasarkan hasil di atas, dapat ditarik kesimpulan bahwa secara umum, kecenderungan penguasaan konsep tubuh manusia pada sub konsep sistem pencernaan, mahasiswa Program S1 PGSD UPI Kampus Cibiru berada pada tingkat tinggi.

TABEL

HASIL TES PENGUASAAN KONSEP SISTEM TRANSPORTASI

\begin{tabular}{|c|c|c|c|}
\hline SKOR & $\mathrm{F}$ & $\%$ & KATEGORI \\
\hline $\mathrm{X} \geq 15$ & 3 & 7,5 & Tinggi \\
$14<\mathrm{X}<8$ & 37 & 92,5 & Sedang \\
$\mathrm{X} \leq 7$ & - & - & Rendah \\
\hline Jumlah & 40 & 100 & \\
\hline
\end{tabular}

Dari tabel di atas terlihat bahwa penguasaan konsep tubuh manusia pada sub konsep sistem transportasi, mahasiswa Program S1 PGSD UPI Kampus Cibiru 7,5 \% berada pada kategori tinggi, 92,5\% berada pada kategori sedang, dan $0 \%$ berada pada kategori rendah.

Berdasarkan hasil di atas, dapat ditarik kesimpulan bahwa secara umum, kecenderungan penguasaan konsep tubuh manusia pada sub konsep sistem transportasi, mahasiswa Program S1 PGSD UPI Kampus Cibiru berada pada tingkat sedang.

TABEL

HASIL TES PENGUASAAN KONSEP SISTEM PERNAFASAN

\begin{tabular}{|c|c|c|c|}
\hline SKOR & $\mathrm{F}$ & $\%$ & KATEGORI \\
\hline $\mathrm{X} \geq 15$ & 7 & 17,5 & Tinggi \\
$14<\mathrm{X}<8$ & 33 & 82,5 & Sedang \\
$\mathrm{X} \leq 7$ & - & - & Rendah \\
\hline
\end{tabular}




\begin{tabular}{|c|c|c|c|}
\hline Jumlah & 40 & 100 & \\
\hline
\end{tabular}

Dari tabel di atas terlihat bahwa penguasaan konsep tubuh manusia pada sub konsep sistem transportasi, mahasiswa Program S1 PGSD UPI Kampus Cibiru 17,5 \% berada pada kategori tinggi, $82,5 \%$ berada pada kategori sedang, dan $0 \%$ berada pada kategori rendah.

Berdasarkan hasil di atas, dapat ditarik kesimpulan bahwa secara umum, kecenderungan penguasaan konsep tubuh manusia pada sub konsep sistem pernafasan, mahasiswa Program S1 PGSD UPI Kampus Cibiru berada pada tingkat sedang.

TABEL

HASIL TES PENGUASAAN KONSEP ALAT INDERA

\begin{tabular}{|c|c|c|c|}
\hline SKOR & F & $\%$ & KATEGORI \\
\hline $\mathrm{X} \geq 21$ & 20 & 50 & Tinggi \\
$20<\mathrm{X} \prec 11$ & 20 & 50 & Sedang \\
$\mathrm{X} \leq 10$ & - & - & Rendah \\
\hline Jumlah & 40 & 100 & \\
\hline
\end{tabular}

Dari tabel di atas terlihat bahwa penguasaan konsep tubuh manusia pada sub konsep alat indera, mahasiswa Program S1 PGSD UPI Kampus Cibiru 50\% berada pada kategori tinggi, 50\% berada pada kategori sedang, dan $0 \%$ berada pada kategori rendah.

Berdasarkan hasil di atas, dapat ditarik kesimpulan bahwa secara umum, kecenderungan penguasaan konsep tubuh manusia pada sub konsep alat indera, mahasiswa Program S1 PGSD UPI Kampus Cibiru berada pada tingkat sedang.

Penguasaan mahasiswa Program S1 PGSD UPI Kampus Cibiru dalam konsep tubuh manusia, sub konsep sistem rangka dan sistem otot, sub konsep sistem pencernaan, sub konsep sistem transportasi, sub konsep sistem pernafasan, dan sub konsep alat indera, berdasarkan kategori (tinggi, sedang, dan rendah) secara keseluruhan dapat disajikan kedalam bentuk grafik sebagai berikut :

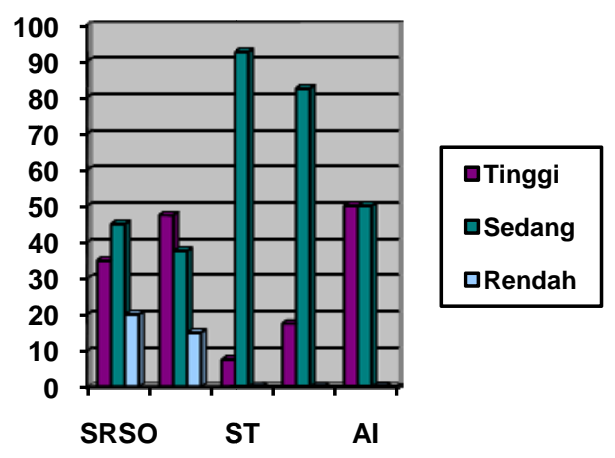

GRAFIK: PENGUASAAN KONSEP TUBUH MANUSIA MAHASISWA PROGRAM S1 PGSD UPI KAMPUS CIBIRU 
Keterangan :

Tinggi, $\square$ Sedang, $\square$ Rendah $\square$

$\mathrm{SRSO}=$ Sistem rangka dan sistem otot

$\mathrm{SPr}=$ Sistem Pencernaan

$\mathrm{ST}=$ Sistem transportasi

$\mathrm{SPn}=$ Sistem Pernafasan

$\mathrm{AI}=$ Alat indera

\section{Pembahasan}

Bertitik tolak dari masalah penelitian yang telah dikemukakan pada bagian awal penelitian ini, maka pada bagian ini, analisis atau pembahasan akan dilakukan dalam tiga bagian, yaitu : 1) Tingkat penguasaan konsep tubuh manusia, 2) kesulitankesulitan mahasiswa dalam memahami konsep tersebut, serta 3) faktor-faktor yang mempengaruhi timbulnya kesulitan tersebut.

\section{a. Penguasaan konsep tubuh manusia}

Konsep tubuh manusia yang dibahas dalam penelitian ini terdiri dari $5 \mathrm{sub}$ konsep. Tingkat penguasaan konsep mahasiswa bisa dilihat dari penguasaan sub konsep-sub konsep tersebut.

Secara umum hasil penelitian menunjukkan bahwa penguasaan konsep tubuh manusia mahasiswa Program S1 PGSD UPI Kampus Cibiru terdiri dari 17,5 \% berada pada kategori tinggi, 67,5\% berada pada kategori sedang, dan $15 \%$ berada pada kategori rendah.

Merujuk kepada pendapat Blomm (1974:89) dan Subiyanto (1988:49) seseorang dikatakan telah menguasai konsep dapat ditunjukkan dengan tiga macam kemampuan yang telah dia miliki, yaitu : (1) mampu menterjemahkan artinya mampu membaca, menangkap makna secara harfiah, dan dapat menyatakan dengan cara lain berbeda dengan pendapat aslinya, (2) mampu menginterpretasi yaitu mampu menyimpulkan dari bahan atau ide yang direkam, kemudian diungkapkan menurut pandangan individu itu sendiri, (3) mampu mengekstrapolasi yaitu mampu meramalkan kecenderungan dari konsep tersebut.

Perbedaan penguasaan konsep tubuh manusia untuk masing-masing sub konsep dapat dilihat dari uraian berikut :

\section{1) Penguasaan Sub Konsep Sistem Rangka dan Sistem Otot}

Data hasil penelitian tentang penguasaan konsep sistem rangka dan sistem otot menunjukkan bahwa sebagian besar mahasiswa Program S1 PGSD UPI Kampus Cibiru berada pada kategori sedang (45\%), hanya $35 \%$ mahasiswa yang berada pada kategori penguasaan konsep tinggi, dan $20 \%$ berada pada kategori penguasaan konsep rendah.

Kenyataan di atas menunjukkan suatu hal yang cukup memprihatinkan, jika seorang guru secara umum hanya berada pada tingkat penguasaan konsep sedang dan rendah, agak sulit bagi mereka untuk mengemban tugas sebagai seorang guru yang profesional dalam hal penguasaal materi. Padahal konsep sistem rangka dan sistem otot ini merupakan bahan ajar yang menempati possi cukup penting di sekolah dasar.

Hal di atas menunjukkan bahwa ada kesulitan-kesulitan yang dialami oleh mahasiswa Program S1 PGSD UPI Kampus Cibiru, dalam upaya menguasai konsep tersebut. Kesulitan-kesulitan tersebut dapat terjadi karena beberapa sebab, bisa dari cara perkuliahan yang telah dilakukan, maupun upaya yang kurang maksimal dilakukan oelh dosen dalam membangkitkan motivasi internal para mahasiswa. 
Untuk itu. Setelah kesulitan-kesulitan yang dimiliki oleh mahasiswa dalam penguasaan konsep sistem otot dan sistem rangka diketahui, maka perlua danya tindkan konkrit berupa penelitian lanjutan untuk menemukan cara mengatasi kesulitan-kesulitan tersebut.

\section{2) Penguasaan Sub Konsep Sistem Pencernaan.}

Data hasil penelitian tentang kecenderungan penguasaan sub konsep Sistem Pencernaan menunjukkan bahwa 47,5 \% mahasiswa Program S1 PGSD UPI Kampus Cibiru berada dalam kategori penguasaan tinggi, 37,5\% kategori penguasaan konsep sedang, dan $15 \%$ kategori penguasaan konsep rendah.

Hasil di atas menunjukkan adanya peningkatan dibandingkan dengan penguasaan pada sub konsep sistem rangka dan sistem otot, tetapi kenyataan yang menunjukkan masih lebih dari $50 \%$ mahasiswa yang berada pada penguasaan konsep kategori sedang dan rendah tetap merupakan sesuatu hal yang memprihatinkan. Apalagi kalau kita melihat bahwa sistem pencernaaan merupakan suatu peroses yang lebih mudah dihayati dan dipahami oleh mahasiswa, akrena merupakan proses fisiologis yang dialami dalam kehidupan sehari-hari, yang seharusnya dari apa yang dialami dapat ditarik benang merah dengan apa yang dipelajari.

Kesulitan-kesulitan yang terutama dialami oelh para mahasiswa adalah adanya istilah-istilah latin yang cukup sulit untuk dipelajari dan diingat. Selain itu reka ulang kejadian pencernaan sulit untuk dilakukan. Waktu yang disediakan untuk mempelajari dan menyelami sub konsep ini juga dirasa kurang (hasil wawancara).

\section{3) Penguasaan Sub Konsep Sistem Transportasi}

Data hasil penelitian tentang kecenderungan penguasaan sub konsep Sistem Transportasi menunjukkan bahwa 7,5 \% mahasiswa Program S1 PGSD UPI Kampus Cibiru berada dalam kategori penguasaan tinggi, 92,5\% kategori penguasaan konsep sedang, dan $0 \%$ kategori penguasaan konsep rendah.

Hasil di atas menunjukkan adanya dominansi mahasiswa yang berada pada kategfori penguasaan konsep pada tingkat sedang. Padahal kegioatan mahasiswa dalam perkuliahan cukup aktif, dan mereka cukup menaruh perhatian terhadap materi yang dipelajari, karena terkait erat dengan hal-hal dalam kehidupan sehari-hari yang cukup menarik mereka untuk mengetahuinya. Untuk itu dalam penelitian selanjutnya, diperlukan tindakan-tindakan konkrit, bagaimana caranya agar potensi / hasrat tinggi yang sudah mereka miliki bisa diarahkan untuk meningkatkan penguasaan konsep mereka pada kategori tingkat tinggi.

Kesulitan-kesulitan yang terutama dialami oelh para mahasiswa adalah adanya istilah-istilah latin yang cukup sulit untuk dipelajari dan diingat. Selain itu alat peraga yang disediakan juga tidak terlalu mendukung mereka untuk dapat memahami proses transportasi dengan lebih baik. Alasan lain yang dikemukakan adalah mereka banyak yang berasal dari SMA bukan jurusan IPA (hasil wawancara).

\section{4) Penguasaan Sub Konsep Sistem Pernafasan}

Data hasil penelitian tentang kecenderungan penguasaan sub konsep Sistem pernafasan menunjukkan bahwa 17,5 \% mahasiswa Program S1 PGSD UPI Kampus Cibiru berada dalam kategori penguasaan tinggi, 82,5 \% kategori penguasaan konsep sedang, dan 0\% kategori penguasaan konsep rendah.

Data di atas menunjukkan bahwa ada kecenderungan yang hampir sama pada

penguasaan sub konsep sistem transportasi dengan sistem pernafasan, yaitu 
dominannya mahasiswa yang berada pada kategori penguasaan konsep tingkat sedang. Hal ini dari satu sisi dapat dijadikan modal untuk merubah dan memperbaiki pengausaan konsep mahasisswa ke tingkat pengausaan konsep tinggi. Untuk itu perlu dilakukan kajian mendalam dan usaha untuk melaksanakan tindakan-tindakan konkrit dalam penelitian selanjutnya agar hal tersebut dapat diwujudkan.

Kesulitan-kesulitan yang dialami diantaranya ditunjukkan dengan adanya pemahaman yang baru tentang apa itu sistem pernafasan, kesulitan memahami pernafasan intra sel, dan kurang adanya pembuktian terhadap proses-proses tersebut melalui percobaan sederhana (hasil wawancara).

\section{5) Penguasaan Sub Konsep Alat Indera}

Data hasil penelitian tentang kecenderungan penguasaan sub konsep Alat indera menunjukkan adanya hal yang berbeda dibandingkan pengausaan sub konsep yang lainnya. Pada sub konsep alat indera ditemukan data bahwa $50 \%$ mahasiswa Program S1 PGSD UPI Kampus Cibiru berada dalam kategori penguasaan tinggi, dan $50 \%$ berada pada tingkat penguasaan konsep sedang $0 \%$ kategori penguasaan konsep rendah.

Hal ini peneliti anggap merupakan suatu fenomena yang menarik. Mengapa demikian, sebab sejak awal, dan juag dari hasil wawancara yang penulis peroleh, umumnya mahasiswa menganggap bahwa bahan ajar sub konsep alat indera ini cukup banyak dan cukup sulit. Tetapi hasil tes yang menunjukkan bahwa $50 \%$ mahasiswa berada pada kategori penguasaan tinggi merupakan hasil tertinggi dibandingkan penguasaan sub konsep yang lain. Hal ini mengindikasikan bahwa dengan anggapan jumlah materi dan tingkat kesulitan ternyata berpengaruh dengan usaha mereka untuk memperoleh hasil yang lebih baik.

\section{b. Kesulitan-kesulitan mahasiswa Program S1 PGSD UPI Kampus Cibiru dalam memahami konsep Tubuh Manusia}

Data hasil penelitian ini menunjukkan bahwa banyak mahasiswa Program S1 PGSD UPI Kampus Cibiru memiliki tingkat penguasaan sedang dan rendah untuk konsep tubuh manusia, dan secara umum hanya sedikit dari mereka yang memiliki tingkat penguasaan tinggi untuk konsep tubuh manusia. Hal di atas dapat dijadikan sebagi suatu indikasi bahwa mereka memiliki kesulitan dalam upaya memahami dan menguasai konsep tubuh manusia.

Data yang diperoleh peneliti dari hasil wawancara dengan mahasiswa diperoleh adanya beberapa hal yang merupakan jenis kesulitan yang mereka alami. Yaitu pertama, sukarnya mereka memahami konsep tubuh manusia karena masalah waktu perkuliahan yang terlalu singkat. Yang kedua, kurang memadainya baik dalam hal jumlah maupun macam alat peraga yang tersedia di laboratorium IPA UPI Kampus Cibiru yang berkaitan dengan tubuh manusia.

Untuk kesulitan pertama bisa dimaklumi, karena terjadi adanya pengurangan jumlah SKS mata kuliah Konsep dasar IPA yang semula 4 SKS pada waktu Program D-II PGSD menjadi 3 SKS sesudah menjadi Program S1 PGSD. Hal ini tentunya sangat berpengaruh terhadap waktu perkuliahan, tetapi walaupun begitu diperlukan adanya upaya untuk membuat pengurangan jumlah SKS tidak terlalu berpengaruh terhadap efektifitas perkuliahan. 
Kesulitan ke dua terjadi karena Laboratorium UPI Kampus Cibiru saat ini hanya memiliki satu torso tubuh manusia, 2 buah model mata manusia, dan satu model telinga manusia. Jumlah dan macam alat peraga yang sangat sedikit ini tentunya juga ikut berpengaruh terhadap penguasaan dan pemahaman konsep tubuh manusia.

Dua faktor yang menyebabkan terjadinya kesulitan mahasiswa Program S1 PGSD UPI Kampus Cibiru dalam memahami konsep tubuh manusia tersebut, akan dibahas secara rinci dalam uraian berikut :

\section{1) Kurangnya waktu perkuliahan dan efektivitas sistem perkuliahan.}

Kurangnya waktu perkuliahan dapat disiasati dengan meningkatkan efektivitas perkuliahan. Yang dimaksud dengan efektivitas perkuliahan disini adalah proses belajar-mengajar yang dikembangkan oleh dosen untuk mencapai tujuan dari mata kuliah yang telah ditentukan.

Efektivitas proses belajar-mengajar diantaranya tercermin dari keterlibatan, keaktivan, dan pemanfaatan semua komponen yang terkait dan terlibat dalam proses perkuliahan.

Faktor-faktor yang menjadi tolak ukur efektivitas perkuliahan diantaranya adalah metode/pendekatan, alat/media perkuliahan, dan pola interaksi antara mahasiswa dan dosen. Jika semua faktor di atas dapat bergerak secara kompak dan terpadu, maka niscaya tujuan yang ditetapkan akan dapat dicapai.

Hasil penelitian menunjukkan bahwa selama ini perkuliahan yang telah dilaksanakan oleh dosen mata kuliah Konsep dasar IPA di UPI Kampus Cibiru belum efektiv. Hal ini anatara lain terlihat dari metode yang digunakan yaitu metode ceramah, tanya jawab, dan metode pemberian tugas. Diakui pula bahwa dalam menentukan pendekatan yang akan digunakan dalam perkuliahan juga tidak jelas.

\section{2) Kurangnya Alat peraga dan Alat Percobaan di laboratorium}

Walaupun selama ini dalam perkuliahan mata kuliah Konsep dasar IPA dilaksanakan beberapa praktikum, tetapi harus diakui bahwa jumlahnya masih sangat sedikit. Untuk keseluruhan mata kuliah Konsep dasar IPA hanya dilaksanakan tujuh kali praktikum, dan untuk konsep tubuh manusia dilakukan dua kali praktikum, yaitu praktikum sistem pencernaan makanan dan praktikum golongan darah.

Praktikum merupakan metode yang sangat sesuai untuk perkuliahan Konsep dasar IPA, khususnya pada konsep tubuh manusia. Hal ini didasari oleh asumsi bahawa melalui kegiatan praktikum di laboratorium, mahasiswa akan lebih mudah memahami dan menguasai konsep-konsep tubuh manusia.

Melalui kegiatan praktikum, dosen dapat membawa mahasiswa ke dunia nyata atau situasi sebenarnya, sehingga mereka akan memperoleh pengalaman belajar dengan mempergunakan seluruh indera mereka dan seluruh potensi yang mereka miliki. Seperti kita ketahui setiap konsep yang diperoleh melalui pengalaman langsung akan memberi makna yang lebih kuat dan akan bertahan lama dalam struktur kognisi mahasiswa tersebut.

Melalui kegiatan praktikum, para mahasiswa akan banyak etrlibat dalam berbagai kegiatan yang melibatkan aktivitas fisik maupun mental mereka, yang kesemuanya itu akhirnya akan mampu membuat mereka menguasai konsep secara utuh.

Jelas, bahwa perkuliahan Konsep Dasar IPA yang dilaksanakan melalui kegiatan praktikum di laboratorium akan memberi tingkat efektivitas yang tinggi dan juga hasil yang tinggi untuk penguasaan konsep. 
Berdasarkan uraian di atas, maka upaya peningkatan penguasaan konsep tubuh manusia mahasiswa Program S1 PGSD UPI Kampus Cibiru dapat dilakukan melalui peningkatan efektivitas perkulaiahan melalui penggunaan pendekatan dan metode yang tepat, dan melalui kegiatan laboratorium yang didukung oleh sarana dan prasarana yang memadai.

Sekaitan dengan hasil penelitian di atas penulis mengemukakan beberapa simpulan sebagai berikut.

1. Penguasaan konsep tubuh manusia mahasiswa Program S1 PGSD UPI Kampus Cibiru secara umum menunjukkan 17,5 \% berada pada kategori penguasaan konsep tingkat tinggi, 67,5\% kategori tingkat penguasaan sedang, dan $15 \%$ berada pada kategori penguasaan tingkat rendah. Jadi secara umum kecenderungan penguasaan mahasiswa Program S1 PGSD UPI Kampus Cibiru berada pada tingkat sedang. Penguasaan sub konsep sistem rangka dan sistem otot menunjukkan $35 \%$ mahasiswa berada pada kategori penguasaan konsep tinggi, $45 \%$ berada pada kategori penguasaan konsep sedang, dan $20 \%$ berada pada kategori penguasaan konsep rendah. Penguasaan sub konsep sistem rangka dan sistem otot menunjukkan $35 \%$ mahasiswa berada pada kategori penguasaan konsep tinggi, 45 $\%$ berada pada kategori penguasaan konsep sedang, dan $20 \%$ berada pada kategori penguasaan konsep rendah. Penguasaan sub konsep sistem transportasi menunjukkan 47,5 \% mahasiswa berada pada kategori penguasaan konsep tinggi, $37,5 \%$ berada pada kategori penguasaan konsep sedang, dan $15 \%$ berada pada kategori penguasaan konsep rendah. Penguasaan sub konsep sistem pernafasan menunjukkan 7,5 \% mahasiswa berada pada kategori penguasaan konsep tinggi, $92,5 \%$ berada pada kategori penguasaan konsep sedang, dan $0 \%$ berada pada kategori penguasaan konsep rendah. Penguasaan sub konsep alat indera menunjukkan $50 \%$ mahasiswa berada pada kategori penguasaan konsep tinggi, 50 $\%$ berada pada kategori penguasaan konsep sedang, dan $0 \%$ berada pada kategori penguasaan konsep rendah.

2. Penguasaan konsep tubuh manusia pada mahasiswa Program S1 PGSD UPI Kampus Cibiru yang secara umum berada pada kategori penguasaan konsep tingkat sedang, disebabkan karena adanya kesulitan-kesulitan yang berupa 1) terlalu singkatnya alokasi waktu perkuliahan, yang disebabkan oleh berkurangnya jumlah SKS untuk mata kuliah Konsep dasar IPA untuk SD dari 4 SKS menjadi 3 SKS, yang secara langsung atau tidak langsung berpengaruh terhadap efektivitas perkuliahan, 2) kurangnya lat peraga dan alat percobaan yang berkaitan dengan konsep tubuh manusia yang tersedia di laboratorium IPA UPI Kampus Cibiru.

Berdasarkan hasil yang diperoleh dari penelitian ini, maka disarankan hal-hal sebagai berikut :

1. Perkuliahan yang dilaksanakan untuk mata kuliah Konsep Dasar IPA untuk SD khususnya pada pokok bahasan tubuh manusia ditingkatkan efektivitasnya dengan melalui penggunaan pendekatan dan metode yang sesuai, sehingga kesulitan yang berkenaan dengan pengurangan jumlah SKS untuk mata kuliah ini, yang dengan sendirinya berakibat pengurangan waktu perkuliahan dapat diatasi. Untuk itu diperlukan penelitian lanjutan tentang pendekatan dan metode apa yang paling tepat digunakan sehingga dapat meningkatkan efetivitas perkuliahan yang pada akhirnya 
dapat meningkatkan tingkat penguasaan konsep mahasiswa pada konsep tubuh manusia.

2. Ditingkatkannya kegiatan praktikum di laboratorium, dengan cara menambah alat percobaan maupun alat peraga yang berkaitan dengan konsep tubuh manusia. Penambahan alat percobaan dan alat peraga dapat dilakukan melalui pembelian oleh lembaga UPI Kampus Cibiru, maupun dengan usaha dosen mata kuliah melalui berbagai cara.

\section{DAFTAR PUSTAKA}

Arikunto, S. (1993). Evaluasi Pendidikan. Jakarta: Bumi Aksara.

Bloom, B. (1974). Taxonomy of Educational Objectives. New York : David Mc Kay Company, Inc.

Carin, Arthur, A. \& Sund (1989). Teaching Modern Science, London : Company.

Dahar, R. W. (1988). Teori-Teori Belajar. Jakarta : Erlangga.

Daryanto. (1983). Tujuan, Metode, dan Satuan Pelajaran Dalam Proses Belajar Mengajar, Bandung: Transito.

Dede Margo Irianto. (2006). Modul Konsep Dasar IPA di SD. UPI Kampus Cibiru.

Gagne, R.M. (1985). The Conditions of Learning. New York : Holk, Rinerhart and Winston.

Moh. Surya. (1983). Pengaruh Faktor-Faktor non Intelektual Terhadap Gejala Berprestasi Kurang. Disertasi. Jakarta.

Moh. Uzer Usman. (1990). Menjadi Guru Profesional, Bandung : Remaja Rosda Karya.

Solihin. (1992). Analisis Terhadap Latar Belakang Kemampuan Awal Konsep Dasare IPA Mahasiswa PGSD IKIP Bandung. IKIP Bandung.

Subino. (1987). Kontruksi dan Analisis Tes, Suatu Pengantar Kepada Teori Tes dan Pengukuran. Jakarta. Dikti.

Surahmad. (1986). Pengantar Inte5raksi Belajar Mengajar. Bandung. Tarsito.

Sujana, M. A. (1992). Metode Statistik. Bandung. Tarsito.

\section{BIODATA PENULIS}

H. Dede Margo Irianto adalah dosen pada Universitas Pendidikan Indonesia dpk. UPI Kampus Cibiru Bandung. Penulis menyelesaikan pendidikan pada jenjang magister (S2) Pendidikan IPA SD dari Sekolah Pascasarjana Universitas Pendidikan Indonesia. 